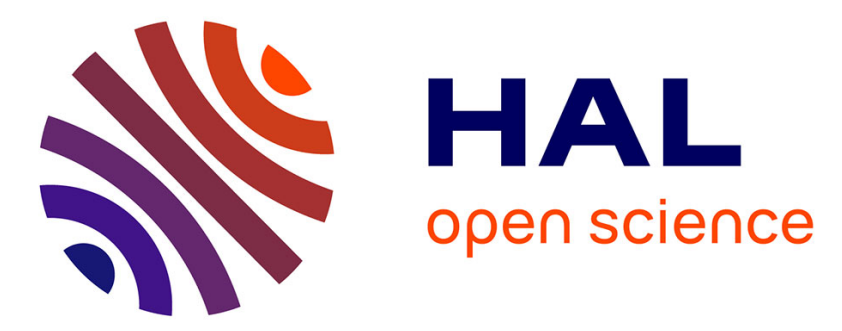

\title{
Hydrothermal silicification and dolomitization in fault system, Irecê Basin (Brazil) - implication for reservoir properties
}

V. La Bruna, F. Bezerra, F. Balsamo, C. Menezes, G. Bertotti, J. Lamarche, P. Richard, F. Agosta, C. Pontes

\section{To cite this version:}

V. La Bruna, F. Bezerra, F. Balsamo, C. Menezes, G. Bertotti, et al.. Hydrothermal silicification and dolomitization in fault system, Irecê Basin (Brazil) - implication for reservoir properties. Fourth Naturally Fractured Reservoir Workshop, Feb 2020, Ras Al Khaimah, France. pp.1-5, 10.3997/22144609.2020622009 . hal-03164555

\section{HAL Id: hal-03164555 \\ https://hal.science/hal-03164555}

Submitted on 10 Mar 2021

HAL is a multi-disciplinary open access archive for the deposit and dissemination of scientific research documents, whether they are published or not. The documents may come from teaching and research institutions in France or abroad, or from public or private research centers.
L'archive ouverte pluridisciplinaire HAL, est destinée au dépôt et à la diffusion de documents scientifiques de niveau recherche, publiés ou non, émanant des établissements d'enseignement et de recherche français ou étrangers, des laboratoires publics ou privés. 


\section{Delft University of Technology}

\section{Hydrothermal silicification and dolomitization in fault system, Irecê Basin (Brazil) - implication for reservoir properties}

la Bruna, V.; Bezerra, F.; Balsamo, F.; Menezes, C.; Bertotti, G.; Lamarche, J.; Richard, P.; Agosta, F.; Pontes, C.

DOI

10.3997/2214-4609.2020622009

\section{Publication date}

2020

Document Version

Accepted author manuscript

Published in

Fourth Naturally Fractured Reservoir Workshop

\section{Citation (APA)}

la Bruna, V., Bezerra, F., Balsamo, F., Menezes, C., Bertotti, G., Lamarche, J., Richard, P., Agosta, F., \& Pontes, C. (2020). Hydrothermal silicification and dolomitization in fault system, Irecê Basin (Brazil) implication for reservoir properties. In Fourth Naturally Fractured Reservoir Workshop [NFR10] EAGE. https://doi.org/10.3997/2214-4609.2020622009

Important note

To cite this publication, please use the final published version (if applicable).

Please check the document version above.

Other than for strictly personal use, it is not permitted to download, forward or distribute the text or part of it, without the consent of the author(s) and/or copyright holder(s), unless the work is under an open content license such as Creative Commons. 


\title{
Hydrothermal silicification and dolomitization in fault system, Irecê Basin (Brazil) - implication for reservoir properties
}

Vincenzo La Bruna ${ }^{1}$, Francisco H. Bezerra ${ }^{1}$, Fabrizio Balsamo ${ }^{2}$, Cristiane P. Menezes ${ }^{1}$, Giovanni Bertotti ${ }^{3}$, Juliette Lamarche ${ }^{4}$, Pascal Richard ${ }^{5}$, Fabrizio Agosta ${ }^{6}$, Cayo Pontes ${ }^{1}$

${ }^{1}$ Departemento de Geologia, Universidade Federal do Rio Grande do Norte, Brazil

${ }^{2}$ NEXT - Natural and Experimental Tectonics Research Group - Department of Chemistry, Life sciences and Environmental Sustainability, University of Parma, Italy

${ }^{3}$ Dept. Geoscience and Engineering, Delft University of Technology, The Netherlands

${ }^{4}$ Aix Marseille Univ, CNRS, IRD, CEREGE, Marseille, France

${ }^{5}$ Shell Global Solutions International BV, LangeKeinweg 40, 2288 GK Rijswijk, Netherlands

${ }^{6}$ Department of Science, University of Basilicata, Italy

\begin{abstract}
The carbonate rocks exposed in the Irecê (Brazil) are pervasively affected by hydrothermal silicification and dolomitization. These mineralizing events drastically changed the original petrophysical properties of the host rock. In order to understand the role played by deformation mechanisms and tectonic evolution of these carbonates on the ingression of the mineralizing fluids, we focused our study on the mineralogical, petrographic, stratigraphic, structural and geochemical characterization of the faulted Neoproterozoic carbonates of the Salitre Formation, central Brazil. In this contribution, we present the first results of a combined outcrop- to micro-scale investigation of the structural evolution of the fracture network responsible for hydrothermal silicification and dolomitization processes.
\end{abstract}




\section{Introduction}

Hydrothermal Silicification and Dolomitization (HSD) processes have been known for more than a century. In the last decades, the role played by faulting and fracturing on HSD has been largely investigated (ie.; Menezes et al., 2019; Mozafari et al., 2019), what highlighted the control exerted by brittle deformation on the petrophysical properties and fluid migration pathways on upper crustal rocks (Figure 1). A detailed understanding of such an interplay is thus necessary to improve our capability of making reliable predictions of fault-related HSD processes in carbonate rocks. One way forward to understand complex underground naturally fractured reservoirs is provided by detailed outcrop studies (ie., La Bruna et al., 2017, 2018), which allow a 3D characterization of fracture networks and fault architecture in order to assess the mechanism associated to the processes of fault initiation and evolution.

\section{a}

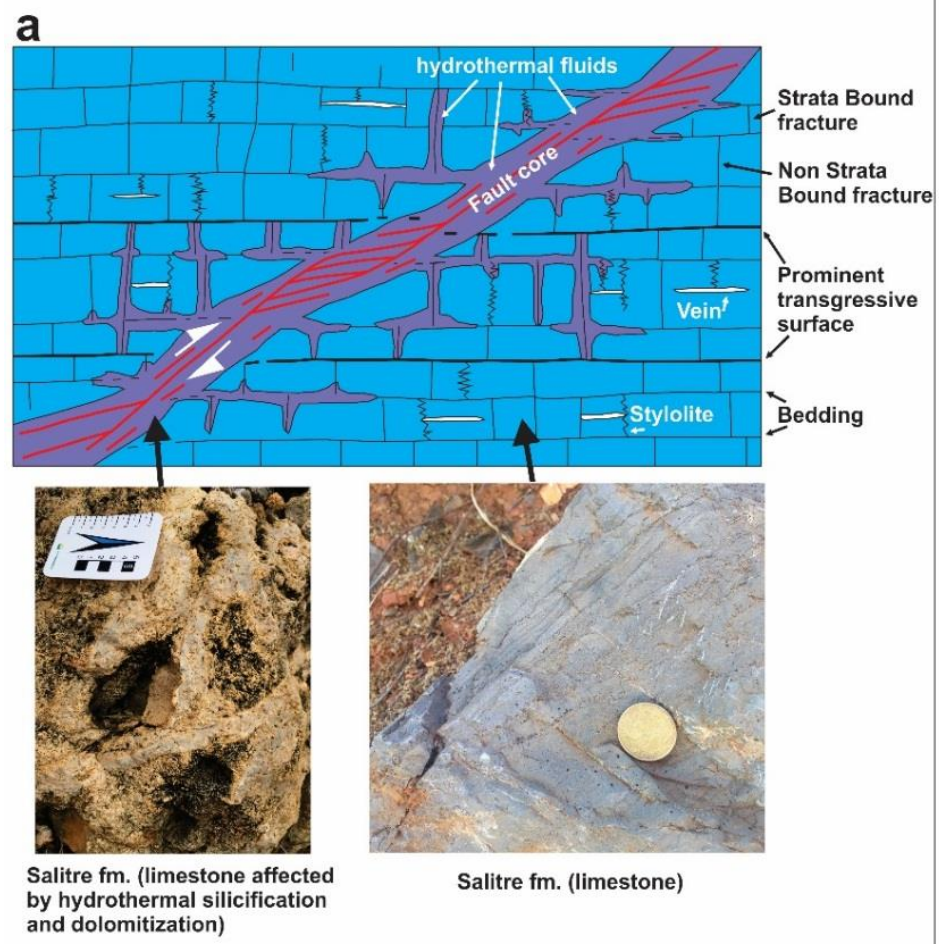

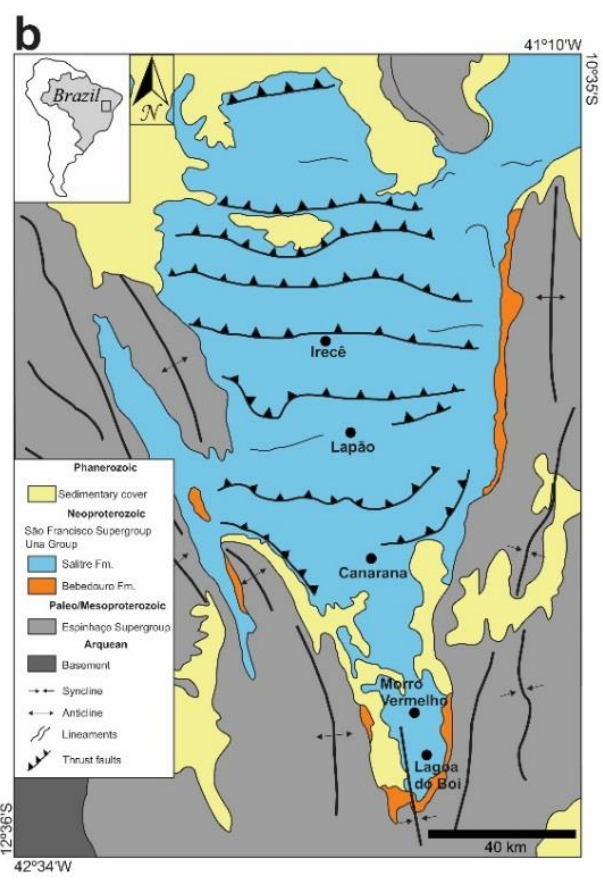

Figure 1 (a) Schematic representation of a thrust zone architecture, with a zoom on the hydrothermal Si/Mg-rich fluids which flow through the fault zone leading to pervasive silicification and dolomitization. Pictures at the bottom represent close ups of the carbonates rocks pertaining to the Salitre Fm.; carbonates affected by HSD, on the left, and pristine carbonates, on the right end side. (b) Geological map of the Irecé basin (modified after Bertotti et al., 2019), all the surveyed outcrops for geological and structural analyses are reported in the figure.

The Neoproterozoic carbonates Salitre Formation cropping out in the Lapão, Canarana, Lagoa do Boi sites and in the Morro Vermelho hill (Irecè Basin, Brazil), where are excavated by a hypogenic cave due to hydrothermal processes (Bertotti et al., 2019). The Focus of this work is to unravel the structural evolution of the faulted carbonates, and document the spatial distribution of the silicified and dolomitized rocks. The results might be of great relevance for exploration and prediction in deeply buried fractured carbonate reservoirs affected by the same processes. 


\section{Methods}

This contribution includes the results of both field and laboratory analyses of the carbonates exposed in three sites, which are $\sim 20 \mathrm{~km}$ distant (Figure 1b). High-resolution, lithostratigraphic logs were combined with systematic sampling of both pristine and altered carbonates. A detailed structural analysis of the fracture pattern was carried out in order to decipher the abutting and crosscutting relationships among fracture/vein sets, stylolites, main slip surfaces, and primary heterogeneities such as bed interfaces. Representative rock samples $(n=35)$ were collected along the southern portion of the Irecê basin for further laboratory analyses. In addition, data gathered from six boreholes, respectively located to the north and south portion of the Morro Vermelho hill, were considered to better define the geometry of the mineralizing halos.

\section{Preliminary results and conclusions}

The Neoproterozoic carbonates of the Salitre Formation were intensely affected by HSD processes along the E-W-striking Canarama/Morro Vermelho fault system, which formed in response to the N-S shortening of the Brasiliano orogeny. The study area shows a complex structural setting. The Salitre Fm. carbonate rocks are affected by both small-scale and largescale folds (Figures 2a and 3a). Moreover, E-W to ENE-WSW striking thrust faults (Figures $3 \mathrm{a}, 3 \mathrm{~b}$ and $3 \mathrm{~d}$ ) crosscut the aforementioned carbonates. These thrusts show a $\mathrm{S}$ to SE transport direction which is quite similar orientation of the tectonic transport direction deciphered for both small- and large-scale folds.

Results of high-resolution structural mapping are consistent with presence of the following features:

- two sets of cross-orthogonal, bed perpendicular fractures and veins striking N-S and E-W, respectively (Figure 3e). Open fractures may display hackles and ribs elements and, hence, are identified as joints;

- bed parallel stylolites which have the typical tooth-like trace, they are localized at bed interfaces within mm-thick, continuous, clay-rich marl levels (Figure 2b). Often, they are present within individual carbonate beds;

- $\quad$ one set of sub-horizontal veins (Figures $3 b$ and $3 c$ );

- one set of bed parallel sheared fractures and veins striking E-W (Figures 3a and 3b);

- two sub-vertical fault sets striking about NE-SW and NW-SE respectively (Figure 2c). The two fault sets form an apparent conjugate strike-slip system, consistent with right-lateral and left lateral motions along the NE and NW faults, respectively;

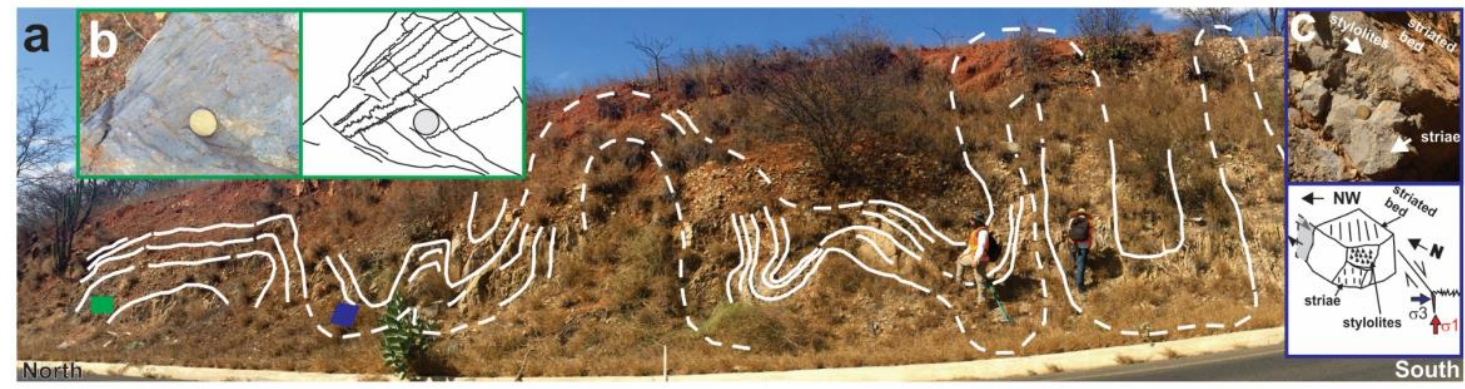

Figure 2 (a) Outcrop view of the irregular crenulation displayed by the carbonates rocks pertaining to the Salitre Fm., Lapao sector. (b) Bed-parallel stylolites and bed-perpendicular fractures and (c) right-lateral sheared fractures. 

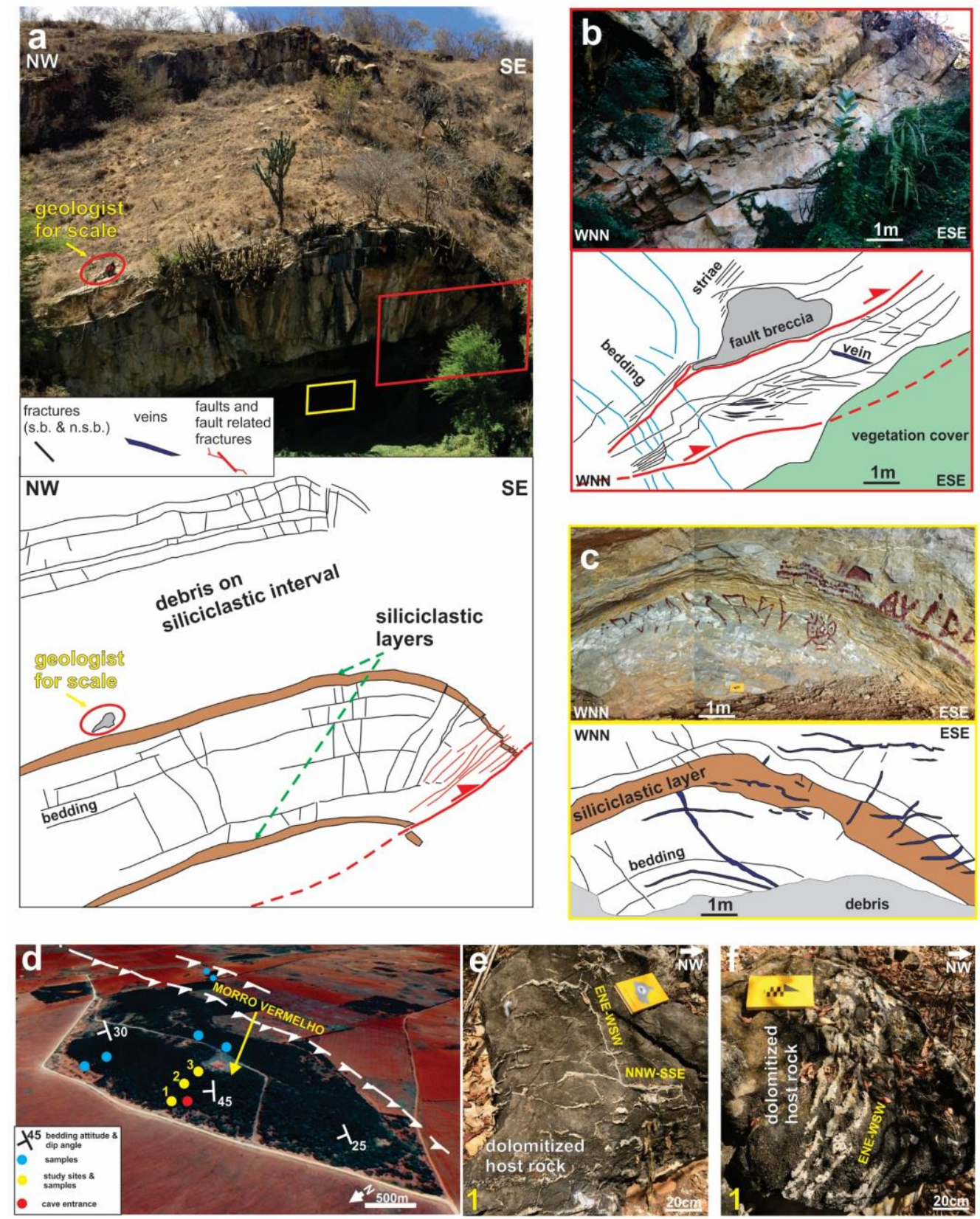

Figure 3 (a) outcrop view of the large, recumbent, isoclinal, thrust-related fold, Camarana site; (b) close-up view of the main thrust fault; (c) close-up view of the outcropping nucleus of the anticline fold; $(\boldsymbol{d})$ panoramic view of the Morro Vermelho study area; $(\boldsymbol{e})$ outcrop view of dolomitized carbonates crosscut by two orthogonal silicified veins, which are interpreted as the oldest structural elements present within the study carbonates; $(\boldsymbol{f})$ close up view of silicified vein cluster exposed along the Morro Vermelho hill.

Abutting and crosscutting relationships among fractures, veins, stylolites, slip surfaces, and primary heterogeneities allows to formulate a preliminary conceptual model regarding the structural evolution of the study area as follows (Fig. 4): (1), background deformation pattern development; (2), bed-tilting led to dolomite-rich en-echelon veins; (3) precipitation of $\mathrm{SiO}_{2}$ from Si-rich fluids sealed fractures and sheared fracture slip surfaces.

Since the HSD processes likely modified the original carbonate petrophysical properties, and partially overprinted the aforementioned structural assemblages, an on-going effort is spent to analyse the origin and structures of fractured silicified and dolomitized carbonate rocks. 


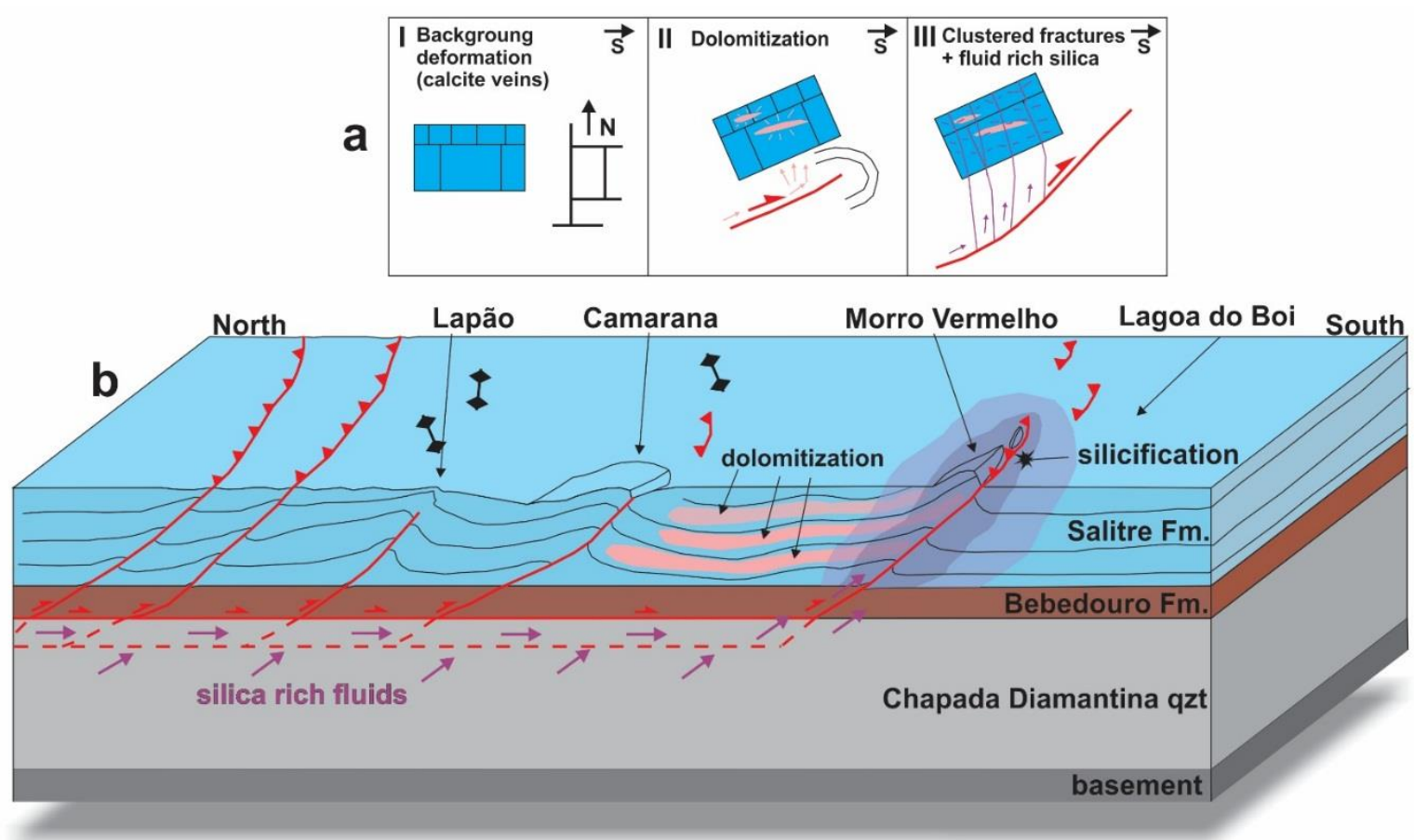

Figure 4 (a) Schematic evolutionary model representing the evolution of the structural network crosscutting the Salitre Fm.; (b) 3D scheme showing the structural architecture of the southern portion of the Irece basin.

\section{References}

Bertotti, G., Audra, P., Auler, A., Bezerra, F.H.R., de Hoop, S., Pontes, C., Prabhakarn, R. and Lima, R. [2019] The Morro Vermelho Hypogenic Karst System: stratigraphy, fractures and flow in a carbonate strike-slip fault zone with implications for a carbonate reservoirs. $A A P G$ Bullettin Under revision.

La Bruna, V., Agosta, F., Prosser, G. [2017] New insights on the structural setting of the Monte Alpi area, Basilicata, Italy. Italian Journal of Geosciences, 136, 220-237.

La Bruna, V., Agosta, F., Lamarche, J., Viseur, S., Prosser, G. [2018] Fault growth mechanisms and scaling properties in foreland basin system: The case study of Monte Alpi, Southern Apennines, Italy. Journal of Structural Geology, 116, 94-113.

Menezes, C.P., Bezerra, F.H.R., Balasamo, F., Mozafari, M., Vieira, M.M., Srivastava, N.K. and de Castro, D.L. [2019] Hydrothermal silicification along faults affecting carbonatesandstone units and its impact on reservoir quality, Portiguar Basin, Brazil. Marine and Petroleum Geology, 110, 198-217.

Mozafari, M., Swennen, R., Balsamo, F., Desouky, H. E., Storti, F., and Taberner, C. [2019] Fault-controlled dolomitization in the Montagna dei Fiori Anticline (Central Apennines, Italy): record of a dominantly pre-orogenic fluid migration. Solid Earth, 10, 1355-1383. 